\title{
$21: 39642835-39636112$
}

National Cancer Institute

\section{Source}

National Cancer Institute. 21:39642835-39636112. NCI Thesaurus. Code C42475.

Physical location of HMGN1_Gene 